\title{
ENTREPRENEURIAL COMPETENCES OF ECONOMIC UNIVERSITY STUDENTS [1]
}

\author{
Angelika Wodecka-Hyjek \\ Cracow University of Economics, Cracow, Poland \\ e-mail: wodeckaa@uek.krakow.pl
}

\begin{abstract}
Aim: The aim of the article is to present the entrepreneurial competences of students of the University of Economics in Cracow. In the course of the pilot studies, a student opinion poll was used.

Methodology: The survey was conducted in 2019 with the use of an inquiry form. The respondents, in the number of 88 , constituted an unrepresentative group, because their choice was determined by the criterion of interest in the issue of entrepreneurial competences. The survey included second-year students of extramural undergraduate (bachelor's) studies, majoring in Accounting and Controlling at the Cracow University of Economics. Participation in the survey was voluntary.
\end{abstract}

Conclusions: As a result of the conducted survey, the author ascertained that the surveyed students are aware of the significance of entrepreneurial competences, both for the development of their career and in undertaking the role of entrepreneurs. The students can point to predispositions, qualities, skills or abilities necessary for activity within the scope of entrepreneurship.

Implications/limitations: The conducted research allows the author to voice the need of and recognise in a "signalling" manner the question of identification of entrepreneurial competences among students of a university of economics. The presented results have many limitations, which stem, above all, from the pilot character of the conducted survey and its limited scope (survey conducted among students of one university only, majoring in one field at extramural studies). Therefore, the results cannot be generalised and their analysis should have a critical character. As has been previously mentioned, the conducted research needs continuation towards its elaboration and basing it on a representative research sample.

Originality/value: The present paper of research character constitutes an attempt at complementing the existing and relatively modest achievements on the Polish ground within the scope of identification of entrepreneurial competences.

Keywords: students' entrepreneurial competences, pilot study, inquiry form, university of economics Paper type: Research paper

\section{Introduction}

Currently, entrepreneurship constitutes one of the most important attributes of market economy. The analysis of source literature allows one to notice that 
ENTREPRENEURIAL COMPETENCES OF ECONOMIC

Angelika Wodecka-Hyjek emphasising both the subjective view of entrepreneurship, in which prevail deliberations oriented towards the functionality of the entrepreneur's actions, identification of her/his qualities and attributes prevail, as well as the view of entrepreneurship as a process, in which entrepreneurship is perceived as a specific way of management. The reflection of the indicated thesis is the interpretation of the notion of entrepreneurship in the perspective of entrepreneurial competences, as an attribute of a modern entrepreneur, both one that runs her/his own company and an intrapreneur active within a corporation. The justification of the claim that entrepreneurship constitutes a key factor of socio-economic development of contemporary countries is the articulation of the competence of initiative and entrepreneurship as key and indispensable for undertaking employment and selfrealisation, in the new European Union programme Education and Training 2020 (European Cooperation).

The aim of this article is to present the entrepreneurial competences of students of the University of Economics in Cracow. The opinions in question were collected with the use of an inquiry form. In the theoretical part, on the basis of a source query of current source literature within the scope of the undertaken problem, exploration of definitions and conceptions of entrepreneurial competences study was performed and the assumed research hypotheses were proposed. Then, the results of the conducted empirical research were presented. The analysis of the obtained material allowed for a preliminary delineation of qualities, attitudes, abilities and skills that constitute the entrepreneurial competences of the examined group of students.

\section{Outline of defining and examining entrepreneurial competences}

The concept of entrepreneurial competences has its source in the research conducted by Boyatzis (1982), who in the early 1980s studied the relation between managerial competences and entrepreneurial competences in a selected group of managers (Glinka and Gudkova, 2011; Draksler and Širec, 2018). Since the 1990s, the research, in that approach, are still being continued (i.a. Chandler and Jansen, 1992; Johannisson, 1993; Bird, 1995; Man et al., 2002; Mitchelmore and Rowley, 2010; Kyndt and Baert, 2015; Zadeh et al. 2017; Solesvick 2019; Kyguoliené and Švipas 2019; Wang et al. 2019). On Polish ground, one can notice a relatively modest amount of research concerning the conceptualisation of the notion of entrepreneurial competences. The broad context for understanding entrepreneurial competences reflects the diversity of their definitions, elaborated within the framework of experience of the cited researchers (Table 1).

In global studies, Chandler and Jansen (1992) tried to answer the question which abilities constitute the core of realisation of a successful venture. They suggested that the core of entrepreneurial competences is constituted by the ability to identify entrepreneurial chances (opportunities). In their research, they 


\begin{tabular}{ll}
\hline Author & Definition \\
\hline Chandler and Jansen (1992) & $\begin{array}{l}\text { The core of entrepreneurial competences is constituted by the } \\
\text { ability to identify entrepreneurial chances (opportunities). }\end{array}$ \\
\hline Johannisson (1993) & $\begin{array}{l}\text { Competences within entrepreneurship are the knowledge that } \\
\text { helps one to answer the following questions: who, when, what, } \\
\text { why and how, as well as the ability to plan, predict and undertake } \\
\text { new economic ventures. }\end{array}$ \\
\hline Bird (1995) & $\begin{array}{l}\text { Competences are connected with entrepreneurial behaviour and } \\
\text { can be learned. In turn, an individual's qualities are set and defi- } \\
\text { ned. The factors that can influence the development of entrepre- } \\
\text { neurial competences are education, professional experience and } \\
\text { entrepreneurial experience. }\end{array}$ \\
\hline Erikson (2002) & $\begin{array}{l}\text { Entrepreneurial competences are the ability to identify, predict, } \\
\text { plan and exploit a chance, connected with the knowledge concer- } \\
\text { ning acquiring resources. }\end{array}$ \\
\hline Man et al. (2002) & $\begin{array}{l}\text { Entrepreneurial competences are the entrepreneur's general } \\
\text { ability to perform work. }\end{array}$ \\
\hline European Union (2007) & $\begin{array}{l}\text { The competences of initiative and entrepreneurship mean a per- } \\
\text { son's ability to carry ideas into effect. They include creativity, } \\
\text { innovativeness and taking risks, as well as the ability to plan } \\
\text { ventures and run them in order to achieve the intended aims. }\end{array}$ \\
\hline Sánchez (2013) & $\begin{array}{l}\text { Entrepreneurial competences emphasise specific qualities of an } \\
\text { individual, such as: sense of one's own effectiveness, proactivity } \\
\text { and the ability to take risks. }\end{array}$ \\
\hline $\begin{array}{l}\text { In the understanding of entrepreneurial competences one should } \\
\text { accentuate innovativeness and creativity in skilful achievement } \\
\text { of aims. }\end{array}$ \\
\hline
\end{tabular}

ENTREPRENEURIAL COMPETENCES OF ECONOMIC

Angelika Wodecka-Hyjek

Table 1. Chosen definitions of entrepreneurial competences

Source: author's own elaboration on the basis of (Chandler and Jansen, 1992; Johannisson, 1993; Bird, 1995; Erikson, 2002; Man et al., 2002; Key Competences for Lifelong Learning European Reference Framework, 2007; Sánchez, 2013; Lans et al., 2014; Zadeh et al., 2017; Draksler and Širec, 2018.

analysed combinations of individual competences with three basic sets of skills: entrepreneurial, managerial and professional-technical skills of a successful entrepreneur (quoted from: Draksler and Širec, 2018). In the research conducted by Johannisson (1993), the dominant context was constituted by knowledge and ability to plan, predict and undertake new economic ventures. Bird (1995) concluded that competences are connected with entrepreneurial behaviour and can be learned. In turn, an individual's qualities are set and defined. In the researcher's view, the factors that can influence the development of entrepreneurial competences are education, professional experience and entrepreneurial experience. Man et al. (2002) analysed the influence of entrepreneurial competences on competitiveness of small and medium enterprises. They defined entrepreneurial competences as the entrepreneur's general ability to perform work. They noticed that opportunities, organisation, strategy, involvement, relations and conceptual competences of an entrepreneur are positively related to competitiveness, organisational possibilities 
ENTREPRENEURIAL COMPETENCES OF ECONOMIC

Angelika Wodecka-Hyjek and effectiveness of action of small and medium enterprises (quoted from: Draksler and Širec, 2018; Zadeh et al., 2016). In turn, Mitchelmore and Rowley (2010) noticed that the context of entrepreneurship concentrates on an individual, while the managerial context concentrates on an organisation. In the view of Sánchez (2013), entrepreneurial competences emphasise specific characteristics of an individual, such as: sense of one's own effectiveness, proactivity and the ability to take risks. In turn, Lans et al. (2014), accentuate innovativeness and creativity in skilful achievement of aims in their understanding of entrepreneurial competences. The researchers identify as well as set of five generic qualities that constitute the basis for entrepreneurial competences and rank the following among them: the ability to seize opportunities, social competences, business competences, specialised competences and entrepreneurial sense of one's own effectiveness. The salience of development and formation of entrepreneurial competences was also recognised in European Union documents. In the report entitled Key Competences for Lifelong Learning - European Reference Framework, competences are defined as a combination of knowledge, skills and attitudes that are relevant in a given situation (2007). In the adopted document, competences are defined as a combination of knowledge, skills and attitudes adequate in a given situation. Key competences, on the other hand, are those that all people need for self-fulfilment and personal development, for being an active citizen, for social integration and employment. Among key competences, i.a. "Initiative and Entrepreneurship" was distinguished. According to European standards, initiative and entrepreneurship mean a person's ability to carry ideas into effect. They include creativity, innovativeness and taking risks, as well as the ability to plan ventures and run them in order to achieve the intended aims. They constitute support for individual persons, not only in their everyday personal and social life, but also in their workplace, helping them to achieve the awareness of the context of professional work and the ability to seize opportunities; they are the basis for more specific abilities and knowledge necessary to those who undertake ventures of social or commercial character, or participate in such. They should also include the awareness of ethical values and promote good managerial practices.

The said experience allows to notice that except for the attempts at defining competences, initially managerial and later entrepreneurial ones, the dominant research context was constituted by an analysis of the functioning of an entrepreneur within business practice in which success was decided by adequate skills, attitudes and knowledge. The contemporary research discourse directs itself towards the claim that entrepreneurial competences can be obtained through education and training, which has a bearing on ever younger generations undertaking entrepreneurial initiatives (Draksler and Širec, 2018). 
3. Conceptualisation of entrepreneurial competences

The problems in designating the constituents of a conceptual model of entrepreneurial competences constitutes the key concern, undertaken by researchers on the ground of theoretical and practical considerations. As a result of the conducted review of source literature, the conceptual approaches suggested by Man et al. (2002), Moczydłowska (2009), Mitchelmore and Rowley (2010), as well as Kyndt and Baert (2015), Lackéus (2015), Kyguolienė, Švipas (2019) were subjected to analysis. Within the framework of the quoted propositions (Table 2 ), the constituents of the conception of examining entrepreneurial competences were defined.

\begin{tabular}{|c|c|c|c|c|}
\hline $\begin{array}{l}\text { Man et al. } \\
(2002)\end{array}$ & $\begin{array}{l}\text { Mitchelmore } \\
\text { and Rowley } \\
(2010)\end{array}$ & $\begin{array}{l}\text { Kyndt } \\
\text { and Baert } \\
(2015)\end{array}$ & $\begin{array}{l}\text { Lackéus } \\
\text { (2015) }\end{array}$ & $\begin{array}{l}\text { Kyguolienè } \\
\text { and Švipas } \\
(2019)\end{array}$ \\
\hline $\begin{array}{l}\text { - Opportunity } \\
\text { competencies } \\
\text { - Relationship } \\
\text { competencies } \\
\text { - Conceptual } \\
\text { competencies } \\
\text { - Organizing and } \\
\text { leading compe- } \\
\text { tencies } \\
\text { - Strategic com- } \\
\text { petencies } \\
\text { - Commitment } \\
\text { - Competencies } \\
\text { - Learning Com- } \\
\text { petencies } \\
\text { - Personal } \\
\text { strength com- } \\
\text { petencies }\end{array}$ & $\begin{array}{l}\text { - Personality } \\
\text { (social) com- } \\
\text { petences } \\
\text { - Behavioural } \\
\text { (personal) } \\
\text { competences } \\
\text { - Managerial } \\
\text { competences }\end{array}$ & $\begin{array}{l}\text { - Perseverance } \\
\text { - Future plan- } \\
\text { ning } \\
\text { - Observation of } \\
\text { the market } \\
\text { - Orientation to- } \\
\text { wards learning } \\
\text { - Seeing oppor- } \\
\text { tunities } \\
\text { - Awareness of } \\
\text { potential return } \\
\text { on investment } \\
\text { - Decisiveness } \\
\text { - Independence } \\
\text { - Self-know- } \\
\text { ledge } \\
\text { - Building } \\
\text { a network of } \\
\text { cooperation } \\
\text { - Ability to } \\
\text { persuade } \\
\text { - Social and } \\
\text { environmen- } \\
\text { tally conscious } \\
\text { conduct }\end{array}$ & $\begin{array}{l}\text { Knowledge: } \\
\text { - Basic business } \\
\text { Skills: } \\
\text { - Marketing } \\
\text { - skills } \\
\text { - Resource skills } \\
\text { - Opportunity } \\
\text { - skills } \\
\text { - Interpersonal } \\
\text { - skills } \\
\text { - Learning skills } \\
\text { - Strategic skills } \\
\text { Attitudes: } \\
\text { - Entrepreneu- } \\
\text { rial passion } \\
\text { - Entrepreneu- } \\
\text { - rial identity } \\
\text { - Snnovativeness } \\
\text { Self-insight }\end{array}$ & $\begin{array}{l}\text { - Opportunity } \\
\text { seeking } \\
\text { - Persistence } \\
\text { - Commitment } \\
\text { to work con- } \\
\text { tract } \\
\text { - Risk-taking } \\
\text { - Demand for } \\
\text { efficiency and } \\
\text { quality } \\
\text { - Goal seeking } \\
\text { - Information } \\
\text { seeking } \\
\text { - Systematic } \\
\text { planning and } \\
\text { monitoring } \\
\text { - Persuasion and } \\
\text { networking } \\
\text { - Self-confi- } \\
\text { dence }\end{array}$ \\
\hline
\end{tabular}

ENTREPRENEURIAL COMPETENCES OF ECONOMIC

Angelika Wodecka-Hyjek

Table 2. Chosen conceptions of entrepreneurial competences

Source: author's own elaboration on the basis of: Man et al., 2002; Mitchelmore and Rowley, 2010; Kyndt and Baert, 2015; Lackéus, 2015; Kyguolienè and Švipas, 2019.

The broadest approach is suggested by Mitchelmore and Rowley (2010). The set of social competences encompasses such personality traits as: selfconfidence, locus of control, coping with difficulties, tolerance, the ability of self-assessment, self-presentation, and attention to quality. Unquestionably, they are qualities or abilities that decide about the efficiency of action of 
ENTREPRENEURIAL COMPETENCES OF ECONOMIC

Angelika Wodecka-Hyjek individuals, both within organisations and among entrepreneurs who run their own companies. Within the framework of behavioural competences the following were distinguished, among others: the ability to motivate oneself and others, the will to achieve success, creativity, ability to undertake challenges, new tasks, to solve problems or to accept risk and its results. This set encompasses initiative as well, which supposedly means not only to perform one's duties, but also to recognise chances, the will to undertake new tasks and responsibilities, as well as assertiveness, which guarantees conscious respect towards one's own position and that of other people. The set of managerial competences in the described model encompasses aspects related to teamwork, such as: interpersonal communication, ability to formulate aims, persuade, search for information, solve problems or plan systematically. Another elements that are mentioned is being tech-savvy, i.e. able to follow technological changes, lifelong learning, knowledge of the newest and commonly used technological solutions. In the proposition authored by Man et al. (2002), the elaboration on personality competences allows one to notice a substantial similarity to the set put forth by Mitchelmore and Rowley (2010). Apart from the ability to plan, positive attitude, self-evaluation or coping with criticism, the authors also mention time management and maintenance of high energy level. Competences within the scope of recognising opportunities or cooperation and forming relations, as well as competences within the scope of involvement and conceptual ones represent personal qualities and skills. Under that category we can enumerate: recognising and developing opportunities, the ability to build cooperation at both individual and group level, exploiting contacts and connections, persuasion, communication, interpersonal skills and abilities that are reflected in the entrepreneur's behaviour, decision-making skills, absorbing and understanding complex information, taking risks and innovativeness. In turn, strategic, organisational, leadership competences and those within the scope of learning are largely expressed by attributes defined previously as managerial competences. In particular, the following abilities were ranked under that category: to build and implement strategies, to organise resources (internal and external ones; human, financial and technological ones, etc.), to build a team; lifelong learning, proactivity, searching for information, openness to novelties (Draksler and Širec, 2018).

The succeeding propositions, put forth by Kyndt and Baert (2015), Lackéus, (2015) and Kyguolienè and Švipas (2019) define in greater detail the specific attributes that fill set of entrepreneurial competences. Kyndt and Baert (2015) in their proposition enumerate: persistence, future planning, monitoring the market, recognising chances, decisiveness, independence, building a network of cooperation and the ability to convince others to one's own ideas. Awareness of potential return on investment constitutes a certain novelty in relation to the discussed propositions. It emphasises the ability to assess the results of one's 
financial decisions. Other new additions are social and ecological awareness, connected with corporate social responsibility and environmental care, and global consequences of the conducted activity (Draksler and Širec, 2018).

Lackéus (2015) identifies the three main competences in detail by indicating the definition of each of the specific competences. Basic business knowledge defines as value creation, idea generation, opportunities, accounting, finance, technology, marketing, risk, etc. Skills are divided into: marketing skills, resource skills, interpersonal skills, opportunity skills, interpersonal skills, learning skills and strategic skills. Marketing skills are understood as conducting market research, assessing the marketplace, marketing products and services, persuasion, getting people excited about your ideas, dealing with customers, communicating a vision. Resource skills include creating a business plan, creating a financial plan, obtaining financing, securing, access to resources. Opportunity skills are related to recognizing and acting on business opportunities and other kinds of opportunities and product/service/concept development skills. Interpersonal skills are related to leadership, motivating others, managing people, listening, resolving conflict, socializing. Learning skills include active learning, adapting to new situations, coping with uncertainty. Strategic skills are oriented towards setting priorities (goal setting) and focusing on goals, defining a vision, developing a strategy, identifying strategic partners. Entrepreneurial passion and Entrepreneurial identity he associates with achievement and value creation, innovativeness is about radical change, creativity and breaking the rules, self-insight is the knowledge of personal fit with being an entrepreneur or being entrepreneurial.

Kyguolienè and Švipas (2019) understands opportunity seeking as searching for and constantly using opportunities to start a new activity or to improve or expand the existing activity to new areas, products and services. Persistence is above all taking repeated action or switching to an alternative strategy to meet a challenge or overcome an obstacle taking personal responsibility for the performance necessary to achieve goals and objectives. Commitment to work contract is about taking responsibility for your work, keeping your commitments and striving for customer satisfaction. Risk-taking is about seizing the chances of doing something and taking risks and anticipating its consequences. Demand for efficiency and quality means setting yourself requirements, improving the quality of products and services, and taking care of the results of your work. Goal seeking is planning activities and careful decision making. Information seeking is of strategic importance in formulating business strategies, while systematic planning and monitoring helps to implement these decisions and to look for possible deviations and make corrections. Persuasion and networking consist in using thoughtful strategies to influence others or convince them to cooperate. Selfconfidence is related to the belief in their own abilities when performing difficult tasks and taking on new challenges. 
ENTREPRENEURIAL COMPETENCES

OF ECONOMIC

Angelika Wodecka-Hyjek

\section{Research methodology}

\subsection{Research assumptions}

The analysis of the presented research conceptions allows the author to notice that undoubtedly the distinguished sets of specific competences that constitute entrepreneurial competences, decide about the efficiency of action of individuals, both within organisations and in the case of entrepreneurs running their own companies.

The basis for research procedure consisted in a review of chosen conceptual propositions that served to indicate the qualities, skills, attitudes and behaviours that constitute the groundwork for a detailed analysis of the set that allows for an identification of entrepreneurial competences of students of a university of economics.

For the purposes of the research, a broad definition of entrepreneurial competences was adopted, according to which entrepreneurial competences include not only knowledge and abilities, but also creativity, innovativeness and taking risks, as well as the ability to plan ventures and run them in order to achieve the intended aims.

Within the desired set of entrepreneurial competences four categories of aggregate character were distinguished:

1. Personality traits and social roles;

2. Competences within the scope of knowledge and experience;

3. Entrepreneurial awareness;

4. Managerial skills.

In each category of aggregate character, elementary constituents were distinguished, which reflect the qualities, skills, abilities, attitudes and behaviours of a potential entrepreneur.

Within the framework of competences connected with knowledge and experience, the context of education within the scope of entrepreneurship was evoked, as well as the perception of the status of an entrepreneur (as a lifestyle, professional choice, means of self-fulfilment, professional success). Previous experience connected with entrepreneurship and running one's own company or plans connected with it, as well as patterns drawn from parents' and friends' experience in conducting a business activity and cultural patterns were taken into account too.

Such qualities as: self-confidence, diligence, initiative, charisma in cooperation with others, coping with difficulties, composure and self-control, self-evaluation, assertiveness, sense of responsibility, as well as communication skills, teamwork and resistance to stress were included in the set of competences concerning personality traits and social roles.

Competences concerning entrepreneurial awareness are related to attributes concerning the recognition and use of opportunities, propensity to take risks 
or anticipating the results of actions taken; the need to achieve; openness to innovative solutions; creative approach to problem solving; ability to adapt to change, as well as persistence and desire of lifelong learning.

Managerial skills include the following abilities: organisation of work, most notably planning (settling action schedules and complying with them), and defining aims and their achievement; taking decisions in an efficient, decided and intentional way (on the basis of previously gathered information); cooperation; problem solving; management skills (defining one's role within a team); leadership, most notably within the scope of searching for compromise solutions.

\subsection{Description of the respondents}

In order to identify the factors determining entrepreneurial competences of students of a university of economics in Poland, a survey was conducted with the use of inquiry form. The inquiry form consisted of 19 questions concerning the problem of entrepreneurial competences and respondent's particulars that characterised the respondents. Most questions were closed-end questions, in one question a five-point evaluation scale was used. The aim was to elicit answers to questions connected with recognition of existing knowledge and experiences of students related to entrepreneurship, defining the attitude of the respondents to undertaking the role of entrepreneur, identification of personality traits and social roles that determine entrepreneurial attitudes and entrepreneurial awareness, which conditions activity within the scope of entrepreneurship. The author also strove to discover the respondents' opinion within the scope of managerial skills and characterise the factors that limit the decision to start one's own business activity. The questionnaire was prepared and distributed in May and June 2019, in a direct way, i.e. with the use of paper forms. Once the first complete version of the questionnaire was prepared, a trial survey was conducted on a chosen group of students. Once the questionnaire was corrected, the distribution of forms began. The respondents, in the number of 88 , constituted an unrepresentative group, because their choice was determined by the criterion of interest in the issue of entrepreneurial competences.

The survey included second-year students of extramural undergraduate (bachelor's) studies, majoring in Accounting and Controlling at the Cracow University of Economic. Participation in the survey was voluntary. In the conducted survey, students of up to 30 years of age took part, women constituted $70.5 \%$ of the respondents, while men constituted 29.5\%. Most respondents are inhabitants of large cities $(44.3 \%)$, although inhabitants of villages constituted a group that was only slightly smaller $(40.9 \%)$. Inhabitants of small towns are $11.4 \%$ of the respondents and $3.4 \%$ are inhabitants of medium-sized towns.

Filled forms were then analysed. The obtained results cannot be generalised for the whole population due to the fact that the sample was an unrepresentative one. For this reason, no detailed statistical analyses were conducted.
ENTREPRENEURIAL COMPETENCES OF ECONOMIC

Angelika Wodecka-Hyjek 
ENTREPRENEURIAL COMPETENCES OF ECONOMIC

Angelika Wodecka-Hyjek

\subsection{Survey results}

The conducted survey covered the identification of factors shaping entrepreneurial competences of students of a university of economics. An analysis of respondents' answers to the question: Have you participated in classes in entrepreneurship so far in the course of your studies and are you interested in that particular question? served as an introduction to the principal research results. A vast majority of the respondents have not yet participated in classes in entrepreneurship during their studies $(51.7 \%)$, but most of them (85.2\%) are interested in that question and intend to participate in such classes. During the realisation of courses in entrepreneurship (Table No 3), the surveyed students expect, above all, to develop skills that would allow them to identify market possibilities, which could constitute an impulse for conducting their own economic activity. At the same time, they expect advice concerning shaping entrepreneurial attitude and practical knowledge connected with the awareness of the procedure of establishing one's own company. They find presentation of cases of entrepreneurs that achieved success, above all in Polish conditions, to be especially valuable in the entrepreneurial education; over $30 \%$ of the respondents appreciates as well the possibility to gain theoretical knowledge in that respect; they are also interested in the current results of research concerning entrepreneurship. In the context of considerable interest in the question of entrepreneurship, it has to be noted that only one third of the respondents, answering the question: Do you have experience connected with entrepreneurship? indicated that at home they learned traditions connected with conducting one's own economic activity (29.4\%). The rest, in turn, in vast majority, did not have family experience in that respect (70.6\%). Among the respondents, only one person conducts their own business activity, fourteen engage in running a family company, whereas the rest (over 50\% of the respondents) declare a desire to start their own business. Despite modest experience and traditions, the respondents perceive the perspective of being entrepreneurs themselves in a positive light. First of all, they see conducting their own economic activity as a means of self-fulfilment (70.05\%) and consider it an attractive professional choice, which allows one to earn money and grow rich, and often guarantees professional success.

Table 3. Desired educational goals within the scope of entrepreneurship

Source: author's own research.

\begin{tabular}{lll}
\hline Desired educational goals within the scope of entrepreneurship & $\begin{array}{l}\text { Number of } \\
\text { answers } \\
\text { (N=88) }\end{array}$ & $\begin{array}{l}\text { Percentage } \\
\text { share of } \\
\text { answers }\end{array}$ \\
\hline Shaping the ability to identify market possibilities & 67 & $76.1 \%$ \\
\hline $\begin{array}{l}\text { Help in creating an entrepreneurial attitude } \\
\text { and starting one's own company }\end{array}$ & 57 & $64.8 \%$ \\
\hline Presenting examples of entrepreneurs that achieved success & 48 & $54.5 \%$ \\
\hline Gaining theoretical knowledge & 29 & $33.0 \%$ \\
\hline Presenting research results within the scope of entrepreneurship & 16 & $18.2 \%$ \\
\hline
\end{tabular}


As far as personality traits and social roles necessary to take initiative with regard to entrepreneurship are concerned (Table No 4), the respondents most often paid attention to communication skills and the ability to recognise problems before their results appear. A potential entrepreneur, in the respondents' opinion, should possess the ability of critical self-evaluation, be able to acknowledge their own mistakes, display assertiveness and confidence in their own opinions, prefer teamwork, as well as be resistant to stress and behave in an efficient, rational way in problem situations, controlling their actions.

\begin{tabular}{lll}
\hline $\begin{array}{l}\text { Desired personality traits and social qualities of an } \\
\text { entrepreneur }\end{array}$ & $\begin{array}{l}\text { Number of an- } \\
\text { Swers (N=88) }\end{array}$ & $\begin{array}{l}\text { Percentage share } \\
\text { of answers }\end{array}$ \\
\hline Efficient communication skills & 68 & $77.3 \%$ \\
\hline Ability of preventive problem solving & 60 & $68.2 \%$ \\
\hline Ability of critical self-evaluation & 59 & $67.0 \%$ \\
\hline Ability to acknowledge one's own mistakes & 56 & $63.7 \%$ \\
\hline Assertiveness and the ability to defend one's own opinions & 53 & $60.0 \%$ \\
\hline Teamwork skills & 48 & $54.5 \%$ \\
\hline Caution and self-control & 36 & $41.0 \%$ \\
\hline Resistance to stress & 24 & $27.3 \%$ \\
\hline Coping in a problem situation & 20 & $22.7 \%$ \\
\hline
\end{tabular}

The abilities and qualities conditioning entrepreneurial activity (Table 5) that the respondents pointed to as the key ones are the following: the ability to adapt to change and search for innovative solutions, openness to learning and acquiring new skills, as well as the facility to adjust to the surrounding conditions. They also recognise the fact that the prerequisite of success in business is the need to achieve and persistence in action, despite defeat, search for creative solutions and propensity to take risks, as well as constant search for and using opportunities.

\begin{tabular}{lll}
\hline Attributes of entrepreneurial awareness & $\begin{array}{l}\text { Number of an- } \\
\text { Swers (N=88) }\end{array}$ & $\begin{array}{l}\text { Percentage } \\
\text { share of answers }\end{array}$ \\
\hline I accept changes and innovative solutions & 78 & $88.6 \%$ \\
\hline I am open to learning and acquiring new skills & 70 & $79.5 \%$ \\
\hline I easily adjust to the surrounding conditions & 56 & $63.6 \%$ \\
\hline I feel the need to achieve & 46 & $52.3 \%$ \\
\hline I am not discouraged in problem situations or in case of failure & 36 & $41.0 \%$ \\
\hline I search for creative solutions & 34 & $38.6 \%$ \\
\hline I have a propensity to take risks & 28 & $31.8 \%$ \\
\hline I constantly search for and use arising opportunities & 28 & $31.8 \%$ \\
\hline
\end{tabular}

ENTREPRENEURIAL COMPETENCES OF ECONOMIC

Angelika Wodecka-Hyjek

Table 4. Desired personality traits and social qualities of an entrepreneur Source: author's own research.

Table 5. Attributes of entrepreneurial awareness Source: author's own research. 
ENTREPRENEURIAL COMPETENCES OF ECONOMIC

Angelika Wodecka-Hyjek
The qualities of an effective and successful entrepreneur (Table No 6) that were ranked highest by the respondents are: organisational skills and the ability to plan, which is attested not only by the mean value (3.88 and 3.97, respectively), but, first and foremost, the median value, which in both of the said cases equalled 4 , which means that in the view of $50 \%$ of the respondents the importance of the said abilities is high and very high. At the same time, in case of organisation skills the evaluation was more diversified ( $\mathrm{IQR}=1.5$ ) than in the case of planning $(\mathrm{IQR}=1)$. In turn, abilities within the scope of decision-making, management and leadership constituted an important element of shaping managerial skills for a part of the respondents, whereas for others it was of little importance (median equal to 3 ).

\begin{tabular}{llll}
\hline \multirow{2}{*}{ Skills within the scope of } & \multicolumn{2}{l}{ Respondents altogether } & IQR \\
\cline { 2 - 4 } & & M & 1 \\
\hline Decision-making & 3.5 & 3 & 1 \\
\hline Planning & 3.88 & 4 & 1.5 \\
\hline Organisation & $3.97 \%$ & 4 & 1 \\
\hline Management & 3.40 & 3 & 1 \\
\hline Leadership & $3.18 \%$ & 3 &
\end{tabular}

The last question raised in the survey was the issue of recognising factors that limit the decision about conducting one's own business activity (Table No 7).

Table 6. Managerial skills in the view of the surveyed students - arithmetic average M - median IQR interquartile range

Source: author's own research.

Table 7. Activity barriers with regard to entrepreneurship in the students' view Source: author's own research.
In that respect, the respondents pointed to insufficient financial means as the fundamental barrier that limits their activity. What is crucial, they identified insufficient knowledge as the second most important factor, which attests to their reasonable and earnest attitude towards the survey. Another limitation they 
indicated was lack of idea for a business activity. They also noticed that education gaps can constitute an important barrier, yet the majority of them declared that they are familiar with instances of entrepreneurs without higher education who achieved success on the market. Moreover, they would expect professional support from public institutions, since a vast majority does not have the possibility to acquire knowledge and obtain help from entrepreneurs in their families or among friends. Only few respondents declared reluctance to undertaking professional work, as well as the will to preserve the tradition of undertaking hired labour only.

\subsection{Discussion of results}

The presented analysis of the survey results within the scope of identification of entrepreneurial competences among students of a university of economics allows the author to conclude that the young students of the Cracow University of Economics subjected to the survey are aware of the significance of entrepreneurial competences, both in the development of their professional career and in taking the role of entrepreneur in a situation in which they would choose conducting their own economic activity. The students can point to predispositions, qualities, skills or abilities necessary for activity within the scope of entrepreneurship.

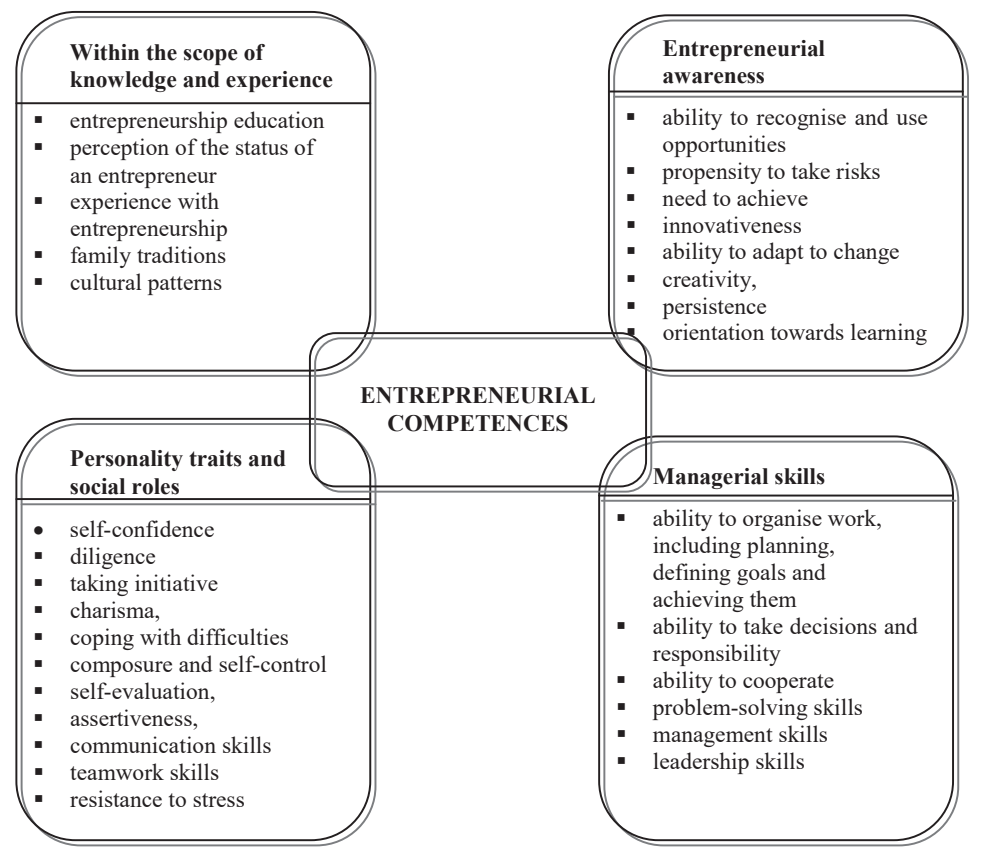

Among the key competences within the scope of entrepreneurship (Figure No. 1), they emphasise problem-solving skills, communication skills, ability to adapt to change and to the surroundings, as well as the ability of self-evaluation,
ENTREPRENEURIAL COMPETENCES OF ECONOMIC

Angelika Wodecka-Hyjek
Figure 1. Set of entrepreneurial competences indicated in the survey

Source: author's own elaboration. 
ENTREPRENEURIAL COMPETENCES OF ECONOMIC

Angelika Wodecka-Hyjek diligence, self-confidence, coping with difficulties and the sense of responsibility. They believe that innovativeness, creativity, motivation, the need to achieve, persistence and the will to learn for the whole life have significant influence on entrepreneurial activity.

Irish and Iranian students also show similar features as in the case of Polish students, which create entrepreneurial competences (Zadeh et al., 2017). As a result of the comparative research conducted, it was shown that productive thinking, motivation, interpersonal skills and leadership are the basic competences in the field of entrepreneurship that should be developed in an educational context. In addition, a positive attitude, competitiveness, determination, questioning everything, creativity as well as controlling emotions, coping with stress, the ability to make decisions or the willingness to take challenges allow you to look at the market from a different perspective, which inspires and encourages young people to connect the future with running their own companies. The conclusions drawn are also confirmed by the research conducted among Lithuanian students, which found that students intending to run their own business are characterized by: persistence, goal setting, information-seeking and self-confidence (Kyguolienè and Švipas, 2019). As in foreign studies (Solezvick, 2019), a very important aspect for students of the University of Economics in Cracow is the clear relationship between building entrepreneurial competences and education in the field of entrepreneurship. The surveyed students expect guidelines on shaping an entrepreneurial attitude and practical knowledge related to the knowledge of the procedure of starting a business. They also emphasize managerial skills related to the ability to organize work, team management, leadership and the ability to make decisions in an efficient and effective manner.

Furthermore, they emphasise managerial skills connected with the ability to organise one's work, lead a team, as well as leadership and the ability to take decisions in an efficient and successful way. Despite lack of experience or traditions in conducting their own economic activity, the respondents are interested in taking the role of entrepreneurs and they perceive potential in that respect in acquiring appropriate knowledge and learning appropriate skills, which in the view of the vast majority $(82.2 \%)$ is enabled by studies in Accounting and Controlling. Among the eighty-eight respondents, only six people affirmed decisively that they did not possess the necessary predispositions and that they did not see in themselves entrepreneurial competences.

These opinions correspond to research conducted among students of the National Taiwan University (Wang et al., 2019), who also see a clear potential for shaping entrepreneurial attitudes in study programs and skilful entrepreneurship teaching. Efficient and comprehensive teaching of entrepreneurship, especially in managerial faculties, creates enormous potential in the form of students who could become entrepreneurs in the future. In turn, Lithuanian researchers (Kyguolienè 
and Švipas 2019) in this regard, propose further-reaching solutions in the form of introducing practical classes, internships, fieldwork, simulation games (e.g. setting up and managing a small enterprise in market conditions) to the study programs of business studies. Moreover, contemporary researchers of the problem postulate that the study programs should be extended by teaching entrepreneurship, not only in the fields related to business.

\section{Conclusion}

As a result of the research, it was found that the surveyed students of the University of Economics in Cracow are characterized by predispositions, skills and abilities necessary to start their own business. They appreciate the role of knowledge that they can acquire at the university in the field of entrepreneurship, they are primarily characterized by the ability to communicate effectively, solve problems, work in a team, as well as the ability to self-criticize and acknowledge one's own mistakes. They are aware of the importance of entrepreneurial competences both in the development of their professional career and in taking up the role of an entrepreneur, which is evidenced primarily by the acceptance of changes and innovative solutions, creativity and openness to learning and acquiring new skills. They are also characterized by managerial abilities expressed by the ability to define goals, plan, make decisions and solve problems. They are also aware of the barriers determining their activity in the field of entrepreneurship, among which they particularly emphasize financial limitations and insufficient knowledge necessary to be successful in running their own business.

Undoubtedly, the presented results have numerous limitations. The limitations stem, above all, from the pilot character of the conducted survey and its limited scope (survey conducted among students of one university only, majoring in one field at extramural studies). Therefore, the results cannot be generalised and their analysis should have a critical character. As has been previously mentioned, the conducted research needs continuation towards its elaboration and basing it on a representative research sample.

\section{Notes}

[1] The publication was financed from the means granted to the Cracow University of Economics within the framework of the subsidy for the maintenance of research potential.

\section{References}

Bird, B. (1995), "Towards a theory of entrepreneurial competency", in: Katz, J.A. and Brockhaus, R.H. (Eds.), Advances in entrepreneurship, firm emergence and growth, JAI Press, Greenwich, pp. 51-72.

Boyatzis, R. (1982), The Competent Manager. A Model for Effective Performance, John Wiley and Sons, New York.
ENTREPRENEURIAL COMPETENCES OF ECONOMIC

Angelika Wodecka-Hyjek 
ENTREPRENEURIAL COMPETENCES OF ECONOMIC

Angelika Wodecka-Hyjek
Chandler, G., Jansen, E. (1992), “The founder's self-assessed competence and venture performance", Journal of Business Venturing, Vol. 7 No. 3, pp. 223-236.

Draksler, T.Z., Širec, K. (2018), "Conceptual Research Model for Studying Students Entrepreneurial Competencies", Naše gospodarstvo. Our economy, Vol. 64 No. 4, pp. 23-33.

Erikson, T. (2002), "Entrepreneurial capital: the emerging venture's most important asset and competitive advantage", Journal of Business Venturing, Vol. 17 No. 3, pp. 275-290.

„Europejska współpraca w dziedzinie kształcenia i szkolenia (Ramy ET 2020)”, available at: https://ec.europa.eu/education/policies/european-policy-cooperation/ et2020-framework_pl (accessed 10 October 2019).

Glinka, B., Gudkova, S. (2011), Przedsiębiorczość, Oficyna a Wolters Kluwer Business, Warszawa.

Johannisson, B. (1993), "Entrepreneurial Competence and Learning Strategies", in: Larsson, R, Bengtsson, L., Eneroth, K., Malm, A. (Eds.), Research in Strategic Change, Lund University Press, Lund, pp. 77-99.

„Kompetencje kluczowe w uczeniu się przez całe życie, Europejskie ramy odniesienia (2007)”, Unia Europejska, Luksemburg: Urząd Oficjalnych Publikacji Wspólnot, available at: http://waloryzacja.llp.org.pl/sites/waloryzacja.llp.org.pl/files/keycomp_pl.pdf (accessed 10 October 2019).

Kyguolienè, A., Švipas, L. (2019), "Personal entrepreneurial competencies of participants in experiential entrepreneurship education", Management of Organizations: Systematic Research, Vol. 82 No. 1, pp. 37-51.

Kyndt, E., Baert, H. (2015), "Entrepreneurial competencies: Assessment and predictive value for entrepreneurship", Journal of Vocational Behavior, Vol. 90, pp. 13-25.

Lackéus, M. (2015), Entrepreneurship in Education: What, Why, When, How (OECD Report), available at: https://www.oecd.org/cfe/leed/BGP_Entrepreneurship-inEducation.pdf (accessed 29 August 2020).

Lans, T., Blok, V., Wesselink, R. (2014), "Learning apart and together: towards an integrated competence framework for sustainable entrepreneurship in higher education", Journal of Cleaner Production, Vol. 62 No. 1, pp. 37-47.

Man, T.W., Lau, T., Chan, K.F. (2002), “The competitiveness of small and medium enterprises: A conceptualization with focus on entrepreneurial competencies", Journal of Business Venturing, Vol. 17 No. 2, pp. 123-142.

Mitchelmore, S., Rowley, J. (2010), "Entrepreneurial competencies: a literature review and development agenda", International Journal of Entrepreneurial Behaviour \& Research, Vol. 16 No. 2, pp. 92-111.

Sánchez, J.C. (2013), "The Impact of an Entrepreneurship Education Program on Entrepreneurial Competencies and Intention", Journal of Small Business Management, Vol. 51 No. 3, pp. 447-465.

Solesvick, M.Z. (2019), "Entrepreneurial competence and intentions: the role of higher education", Forum Scientiae Oeconomia, Vol. 7 No. 1, pp. 9-23.

Wang, S.M., Yueh, H.P., Wen, P.Ch. (2019), "How the New Type of Entrepreneurship Education Complements the Traditional One in Developing Entrepreneurial Competencies and Intention", Frontiers in Psychology, Vol. 10, pp. 1-12. 
Zadeh, M.R., Hogan, M., O’Reilly, J., Cunningham, J., Murphy, E. (2017), “Core entrepreneurial competencies and their interdependencies: insights from a study of Irish and Iranian entrepreneurs, university students and academics", International Entrepreneurship and Management Journal, Vol. 13 No. 1, pp. 35-73.
ENTREPRENEURIAL COMPETENCES OF ECONOMIC

Angelika Wodecka-Hyjek 